\title{
Analisis Kekuatan Struktur Hydraulic Lifting Machine Dengan Menggunakan Metode Elemen Hingga
}

\author{
Ahmat Saebudin ${ }^{1}$, Hendri Suryanto ${ }^{2}$, Eva Hertnacahyani Herraprastanti ${ }^{3}$
}

Jurusan Teknik Mesin STT Ronggolawe Cepu

\begin{abstract}
Hydraulic Lifting Machine merupakan jenis alat angkat yang didesain untuk memindahan barang ditempat yang relatif sempit. Dalam mendesain suatu alat selain fungsi dan kegunaannya kekuatan struktur merupakan salah satu aspek yang sangat penting untuk diperhatikan. Struktur tersebut haruslah mampu untuk menanggung beban yang timbul saat beroperasi dan memberikan keamanan bagi penggunanya dari kegagalan struktur. Oleh sebab itu tujuan dari penelitian ini adalah untuk menganalisis kekuatan struktur Hydraulic Lifting Machine dengan menggunakan metode elemen hingga. Berdasarkan hasil dari simulasi yang telah dilakukan dimana nilai tegangan resultan dan defleksi maksimum yang timbul pada struktur Hydraulic Lifting Machine yaitu pada beban kerja $100 \mathrm{~kg}$ tegangan resultannya sebesar 90,62 MPa dengan defleksi maksimum 4,39 mm, pada beban kerja $250 \mathrm{~kg}$ tegangan resultannya sebesar 218,51 MPa dengan defleksi 10,71 mm, pada beban kerja $500 \mathrm{~kg}$ tegangan resultannya sebesar 431,68 MPa dengan defleksi 21,25 mm, pada beban kerja $750 \mathrm{~kg}$ tegangan resultannya sebesar 644,84 MPa dengan defleksi $31,79 \mathrm{~mm}$, dan pada beban kerja maksimal $1000 \mathrm{~kg}$ tegangan resultannya sebesar $858 \mathrm{MPa}$ dengan defleksi 42,33 mm. Berdasarkan pada peraturan BS-5950 Structure Use of Steelwork in Building, nilai batas defleksi maksimumnya tidak boleh lebih dari 7,778 mm. Sedangkan untuk batas tegangan resultannya berdasarkan peraturan Allowable Stress Design (ASD) untuk dinyatakan aman adalah sebesar 149,7 MPa. Sehingga dapat disimpulkan bahwa struktur Hydraulic Lifting Machine layak digunakan dengan beban kerja maksimal $100 \mathrm{~kg}$ dengan angka safety factor 2,5.
\end{abstract}

Keywords: Crane, Metode Elemen Hingga, Tegangan Von Mises.

\section{Pendahuluan}

Dalam dunia industri dan rekayasa terkadang proses pemindahan suatu barang atau benda kerja di tempat yang relatif sempit masih dilakukan dengan tenaga manusia, sehingga hal tersebut dapat memperlambat proses produksi dan menimbulkan rawan terjadinya kecelakaan kerja.

Hydraulic Lifting Machine merupakan jenis alat angkat yang didesain untuk mengatasi permasalah dalam pemindahan barang atau benda kerja di tempat yang relatif sempit. Dalam mendesain suatu alat selain fungsi dan kegunaannya, kekuatan struktur merupakan salah satu aspek yang sangat penting untuk diperhatikan. Struktur tersebut haruslah mampu untuk menanggung beban yang timbul saat beroperasi dan dapat memberikan keamanan bagi penggunanya dari kegagalan struktur.

Metode elemen hingga merupakan metode numerik yang dapat digunakan untuk memecahkan permasalahan dalam bidang rekayasa ataupun bidang fisik lainnya. Penerapan metode elemen hingga dewasa ini telah banyak digunakan dalam berbagai disiplin ilmu rekayasa teknik dan fisika matematis, salah satunya dalam menganalisa kekuatan struktur. Perkembangan metode elemen hingga didukung secara langsung oleh perkembangan teknologi komputer. Peningkatan kemampuan komputer menyebabkan kemungkinan yang semakin besar untuk melakukan analisis persoalan teknik yang besar dan lebih kompleks.

Berdasarkan hal tersebut, penulis termotivasi untuk menganalisis kekuatan struktur hydraulic lifting machine dengan menggunakan software berbasis metode elemen hingga. Hasil analisis simulasi yang didapat nantinya akan dibandingkan dengan hasil analisis secara kalkulasi berdasarkan teori metode elemen hingga.

Dalam analisis ini dimaksudkan untuk mengetahui besarnya tegangan dan defleksi maksimum yang terjadi pada struktur hydraulic lifting machine seperti yang ditunjukkan pada gambar 1.1.

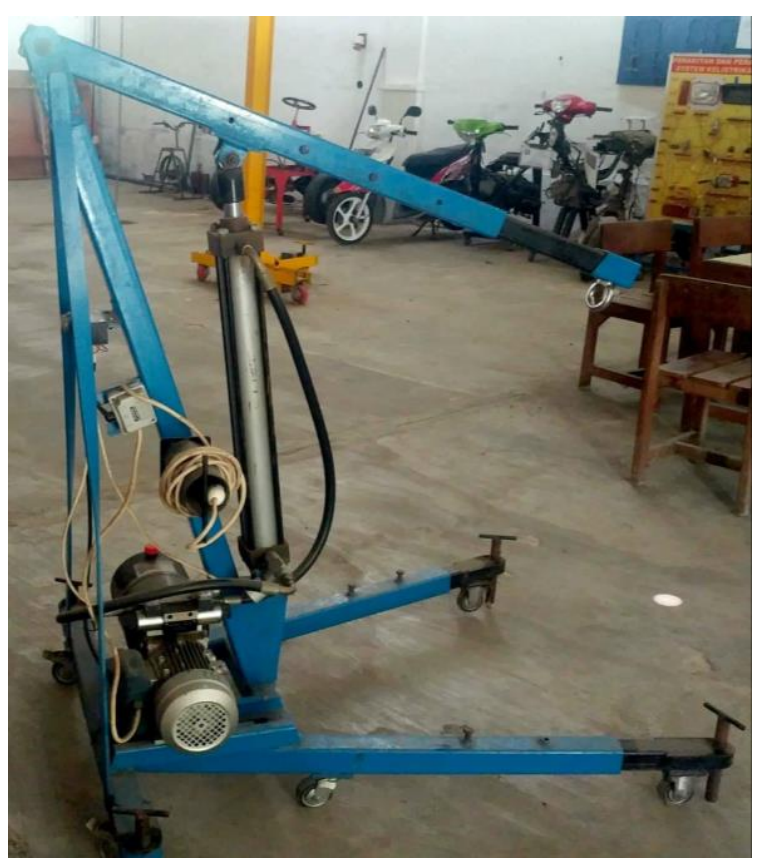

Gambar 1.1 Hydraulic Lifting Machine 


\section{Kerangka Teori}

\subsection{Kajian Pustaka}

Kelana dan Ariatedja (2018), dalam penelitiannya analisis dan optimasi ukuran (size optimization) jib boom hydraulic crane dengan software metode elemen hingga. optimasi dilakukan untuk mengurangi massa pada jib boom hydraulic crane. Hasil dari penelitiannya adalah pada model awal massa geometri mengalami 10,26\% pengurangan. Equivalent stress dan total deformasi yang dimiliki oleh model awal sebesar 230,73 MPa dan 39,907 mm. Pada model th/t $=1$ dan th/tl $>1$ perubahan massa geometri, besar equivalent stress dan total deformasinya adalah $(19,39 \%, 8372,8 \mathrm{~kg}, 45,49$ $\mathrm{mm})$ dan $(18,36 \%, 8744,5 \mathrm{~kg}, 40,573 \mathrm{~mm})$.

Agustin dan Sutantra (2018), dalam penelitiannya yang bertujuan untuk membandingkan kekuatan struktur tower crane Potain MD 900 yang telah di redesign dengan design saat ini menggunakan software berbasis metode elemen hingga. Hasil dari penelitian yang telah dilakukan, didapatkan hasil bahwa pada desain saat ini tegangan maksimum terjadi sebesar 149,488 MPa, sedangkan tegangan minimum yang terjadi sebesar 15,0427 MPa. Umur dari tower crane Potain MD 900 dengan desain saat ini adalah 910.377 cycle. Redesign dilakukan dengan menambahkan seamless pipe pada rangka yang memiliki titik kritis dan frame segiempat yang dihubungkan dengan tali baja menuju tower top. Berdasarkan hasil simulasi redesign jib tower crane Potain MD 900, diketahui bahwa tegangan maksimum yang terjadi adalah sebesar 78,444 MPa, sedangkan tegangan minimum yang terjadi adalah sebesar 13,2941 MPa. Umur yang dimiliki oleh desain hasil redesign adalah 2.602 .671 cycle.

Mohammad dan Sugiyanto (2009), melakukan analisis tegangan dan regangan pada struktur container crane kapasitas 40 ton menggunakan metode elemen hingga. Hasil dari penelitiannya adalah nilai displacement, tegangan dan regangan terbesar terjadi pada daerah boom. Pada pembebanan diposisi tersebut nilai displacement maksimum sebesar 296,01 mm, dengan nilai regangan maksimum sebesar 0,00636 mm. Sedangakan tegangan von Mises maksimum sebesar 130MPa, berdasarkan teori kegagalan von Mises dapat diketahui bahwa container crane masih dalam kondisi aman saat dikenai beban kejut, karena nilai tegangan von Mises maksimum yang terjadi masih dibawah kekuatan luluh (yield strength) material yang digunakan.

\subsection{Konsep Metode Elemen Hingga}

Metode elemen hingga (MEH) adalah salah satu metode numerik yang dapat digunakan untuk memperoleh solusi dari berbagai persoalan teknik. Dasar dari metode elemen hingga adalah membagi benda kerja (kontinum) menjadi elemenelemen kecil (elemen diskrit) yang jumlahnya berhingga, sehingga dapat menghitung reaksi akibat beban (load) pada kondisi batas (boundary condition) yang diberikan. Dengan menggunakan metode elemen hingga kita dapat mengubah suatu masalah yang memiliki derajat kebebasan (degree of freedom) tertentu sehingga proses pemecahan masalahnya lebih sederhana. Metode elemen hingga (MEH) banyak digunakan untuk menghitung struktur yang diakibatkan pembebanan ataupun pengaruh lain pada struktur sehingga menyebabkan terjadinya regangan yang juga disertai tegangan dalam dan reaksi titik tertahan.
Tujuan utamanya adalah untuk memperoleh nilai pendekatan (bukan eksak) tegangan dan regangan yang terjadi pada suatu struktur, pendekatan dengan elemen hingga merupakan suatu analisa berdasarkan asumsi tegangan atau regangan, bahkan juga berdasarkan kombinasi dua asumsi tadi dalam setiap elemennya. Dari elemen-elemen tersebut dapat disusun persamaan-persamaan matrik yang bisa diselesaikan secara numerik dan hasilnya menjadi jawaban dari kondisi beban yang diberikan pada benda kerja tersebut. Penyelesaian matematis dengan menghitung invers matrik akan diperoleh persamaan dalam bentuk matrik untuk satu elemen dan bentuk matrik total (global) yang merupakan penggabungan (assemblage) matrik elemen.

Langkah-langkah yang umum digunakan dalam analisis elemen hingga adalah sebagai berikut :

a. Membuat dan memecahkan solusi bagi suatu model menjadi satu atau lebih elemen model.

b. Mengasumsikan suatu fungsi bentuk untuk menyatakan sifat fisik dari elemen-elemen yang dibentuk.

c. Membuat persamaan untuk tiap-tiap elemen.

d. Merangkai matrik global dari persamaan tiap-tiap elemen sehingga membentuk matrik yang menyatakan sifat dari model secara keseluruhan.

e. Memasukkan kodisi batas, keadaan mula-mula, pembebanan dan selanjutnya memecahkan solusi tersebut.

f. Memperoleh nilai-nilai pokok dan yang lain yang ingin diketahui.

Persamaan metode elemen hingga secara umum adalah sebagai berikut:

$\{F\}=[K]\{D\}$

Dimana:

$\{F\}=$ Matriks kolom gaya dan momen pada node elemen

$[K]=$ Matriks kekakuan elemen

$\{D\}=$ Matriks kolom perpindahan translasi node elemen

Sedangkan untuk persamaan matrik kekakuan elemen lokalnya adalah

$$
[K]=\frac{\mathrm{EI}}{\mathrm{L}^{3}}\left[\begin{array}{cccc}
12 & 6 \mathrm{~L} & -12 & 6 \mathrm{~L} \\
6 \mathrm{~L} & 4 \mathrm{~L}^{2} & -6 \mathrm{~L} & 2 \mathrm{~L}^{2} \\
-12 & -6 \mathrm{~L} & 12 & -6 \mathrm{~L} \\
6 \mathrm{~L} & 2 \mathrm{~L}^{2} & -6 \mathrm{~L} & 4 \mathrm{~L}^{2}
\end{array}\right]
$$

Dimana:

$\mathrm{E}=$ Modulus elastisitas material

$\mathrm{I}=$ Momen inersia

$\mathrm{L}=$ Panjang elemen

Matrik kekakuan lokal yang didapatkan kemudian digunakan untuk menentukan nilai matrik kekakuan global 
yang dilakukan dengan prinsip superposisi. Persamaan matrik kekakuan globalnya adalah sebagai berikut

$[K]=[K]_{1}+[K]_{2}+[K]_{\ldots}+[K]_{n}$

3. Metode Penelitian

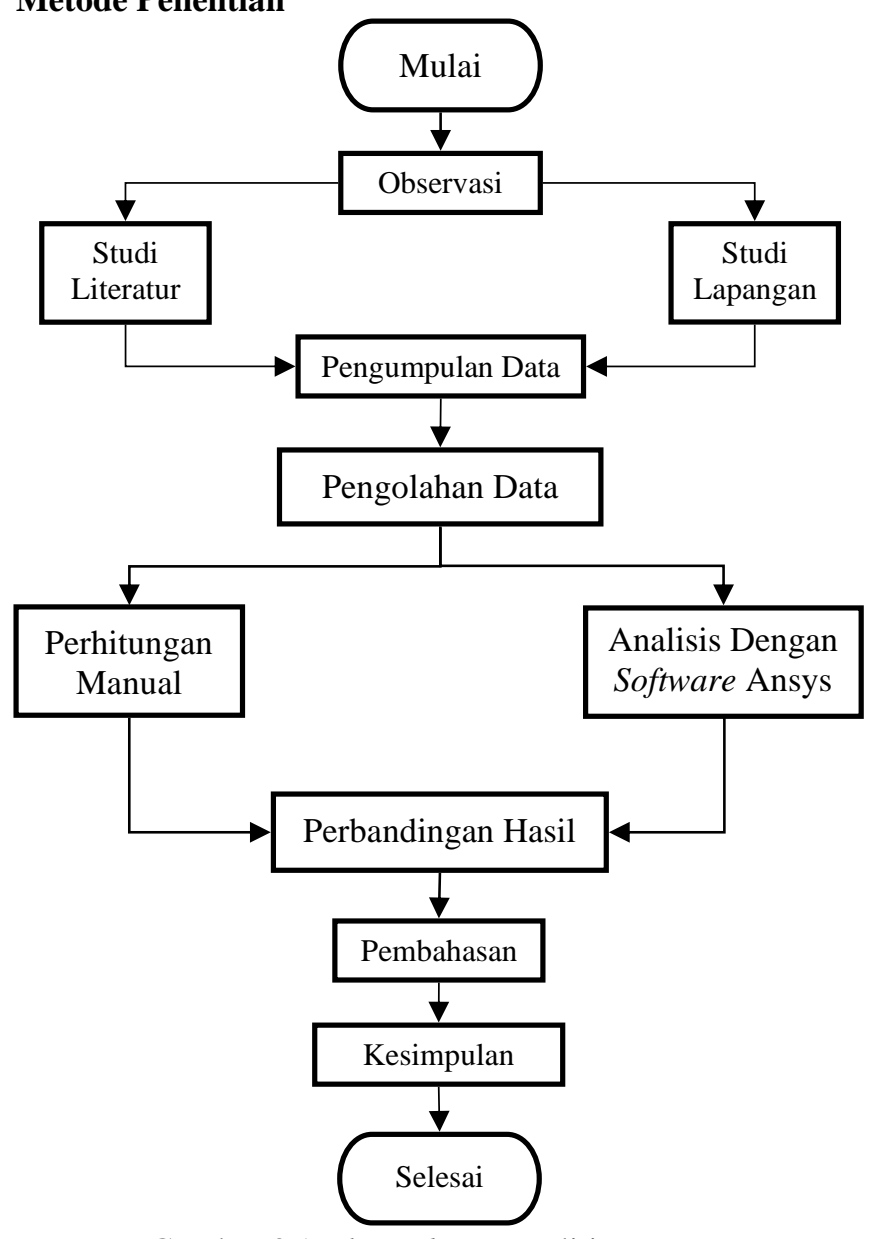

Gambar 3.1 Flow Chart Penelitian

Dalam penelitian ini proses pengumpulan data dilakukan dengan studi literatur dan studi lapangan. Adapun data yang telah penulis kumpulkan adalah data spesifikasi dan dimensi dari hydraulic lifting machine.

Tabel 1 Spesifikasi Utama Hydraulic Lifting Machine

\begin{tabular}{ll}
\hline \multicolumn{2}{c}{ Spesifikasi Utama } \\
\hline Tahun pembuatan & 2015 \\
Tinggi & $1444 \mathrm{~mm}$ \\
Panjang boom minimal & $1400 \mathrm{~mm}$ \\
Panjang boom maksimal & $1700 \mathrm{~mm}$ \\
Maksimal tinggi angkat hidrolik & $900 \mathrm{~mm}$ \\
\hline
\end{tabular}

Rangka pada hydraulic lifting machine menggunakan baja hollow dengan profil berbentuk persegi seperti yang terlihat pada Gambar 3.2 dengan spesifikasi yang tertera pada Tabel 2.

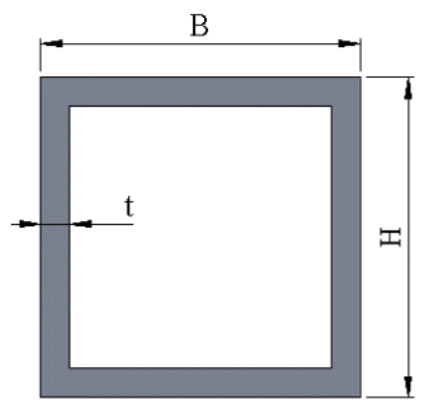

Gambar 3.2 Profil Rangka

Tabel 2 Spesifikasi Dimensi Profil Rangka (Handoko, 2015)

\begin{tabular}{|c|c|c|c|c|c|}
\hline No. & Profil & Bahan & $\begin{array}{c}\text { B } \\
(\mathrm{mm})\end{array}$ & $\begin{array}{c}\mathbf{H} \\
(\mathbf{m m})\end{array}$ & $\begin{array}{c}\mathbf{t} \\
(\mathbf{m m})\end{array}$ \\
\hline 1. & $\begin{array}{l}\text { Rangka } \\
\text { Penopang Dan } \\
\text { Boom }\end{array}$ & $\begin{array}{c}\text { Baja Struktural } \\
\text { ASTM A-36 }\end{array}$ & 60 & 60 & 3,8 \\
\hline 2. & $\begin{array}{l}\text { Rangka } \\
\text { Extention }\end{array}$ & $\begin{array}{c}\text { Baja Struktural } \\
\text { ASTM A-36 }\end{array}$ & 50 & 50 & 4,5 \\
\hline
\end{tabular}

Selain data dimensi, Penelitian ini juga didasari dengan spesifikasi material yang merupakan parameter-parameter vital dalam analisis kekuatan struktur.

Tabel 3 Spesifikasi Material ASTM A-36 (Zainuri, 2010)

\begin{tabular}{lll}
\hline Property & Value & Unit \\
\hline Density & 7860 & $\mathrm{~kg} / \mathrm{m}^{3}$ \\
Tensile Yield Strength & 250 & $\mathrm{MPa}$ \\
Tensile Ultimate Strength & 400 & $\mathrm{MPa}$ \\
Modulus Elasticity & 200000 & $\mathrm{MPa}$ \\
Poisson's Ratio & 0,27 & - \\
\hline
\end{tabular}

Data yang telah dikumpulkan baik dari studi literatur maupun studi lapangan kemudian dilakukan proses analisis. Berikut adalah Flowchart penyelesaian analisis dengan menggunakan metode elemen hingga, yaitu:

\section{Hasil Dan Pembahasan}

\subsection{Defleksi}

Mengacu pada BS-5950 Structure Use of Steelwork in Building, nilai batas maksimal defleksi pada struktur hydraulic lifting machine bernilai $1 / 180$ dari total panjang boom.

$$
\delta \max =\frac{\mathrm{L}}{180}=\frac{1400}{180}=7,78 \mathrm{~mm}
$$

Dimana:

$$
\begin{array}{ll}
\delta \max & =\text { Defleksi maksimum }(\mathrm{mm}) \\
\mathrm{L} & =\text { Panjang boom hydraulic lifting machine }(\mathrm{mm})
\end{array}
$$

Hasil dari simulasi defleksi pada struktur hydraulic lifting machine dengan beban kerja $1000 \mathrm{~kg}$ yang mana defleksi maksimumnya berada pada ujung boom yang ditunjukkan pada gambar 3.3. 


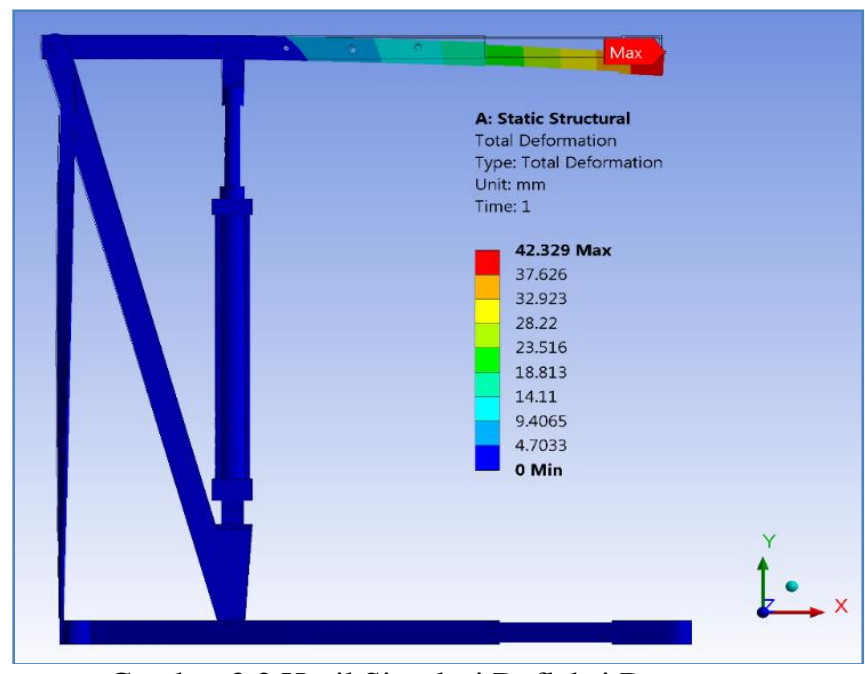

Gambar 3.3 Hasil Simulasi Defleksi Dengan Beban Kerja 1000 kg

Data nilai defleksi maksimum yang timbul pada boom hydraulic lifting machine dari kedua jenis analisis dengan masing-masing kondisi beban kerja yang telah ditentukan ditunjukkan pada tabel 4 .

Tabel 4 Data Perbandingan Hasil Analisis Defleksi

\begin{tabular}{cccc}
\hline \multicolumn{4}{c}{ Total Defleksi $(\delta)$} \\
\hline $\begin{array}{c}\text { Load } \\
(\mathrm{kg})\end{array}$ & $\begin{array}{c}\text { Kalkulasi } \\
(\mathrm{mm})\end{array}$ & $\begin{array}{c}\text { Simulasi } \\
(\mathrm{mm})\end{array}$ & $\begin{array}{c}\text { Margin } \\
(\%)\end{array}$ \\
\hline 100 & 4,043 & 4,388 & 4,1 \\
250 & 10,107 & 10,712 & 2,9 \\
500 & 20,214 & 21,251 & 2,5 \\
750 & 30,321 & 31,79 & 2,4 \\
1000 & 40,429 & 42,329 & 2,3 \\
\hline
\end{tabular}

Berdasarkan pada Tabel 4 menunjukkan bahwa hasil dari analisis defleksi maksimum dari kedua jenis analisis terdapat perbedaan nilai hingga sebesar $4,1 \%$ yang dilukiskan kedalam grafik pada Gambar 3.4 dimana nilai defleksi maksimum yang terjadi pada boom hydraulic lifting machine terhadap nilai batas defleksi ijin yang telah ditentukan yaitu dari kelima jenis pembebanan hanya pada beban kerja $100 \mathrm{~kg}$ nilai defleksi maksimumnya yang berada dibawah nilai defleksi ijin. Sehingga dapat disimpulkan bahwa struktur hydraulic lifting machine aman untuk beban kerja maksimal hingga $100 \mathrm{~kg}$.

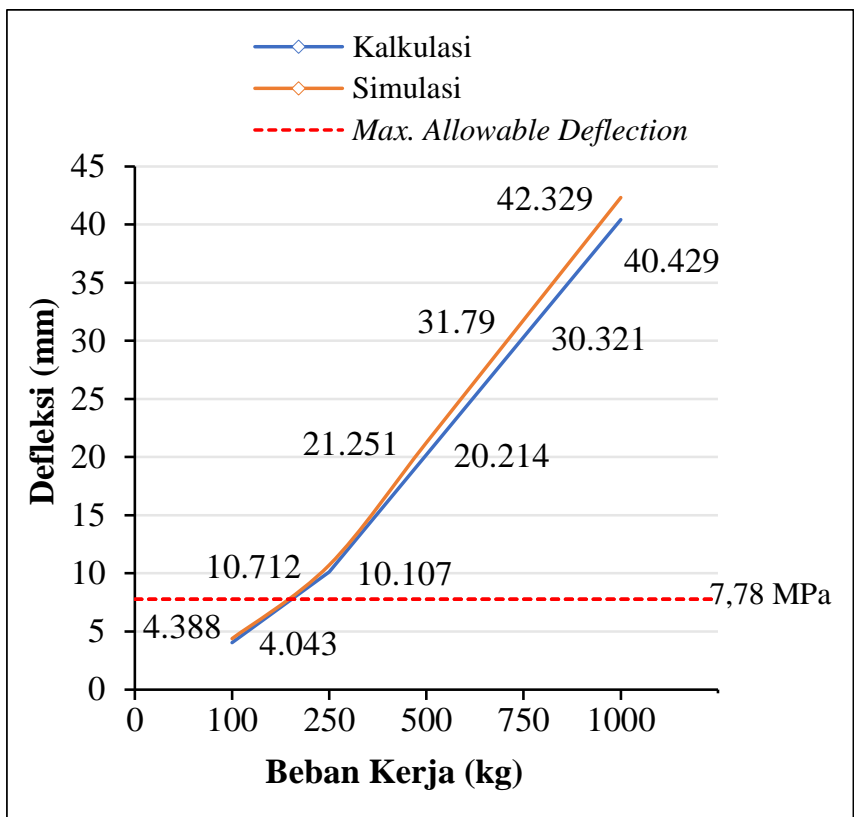

Gambar 3.4 Grafik Hasil Analisis Defleksi Terhadap

Nilai Batas Allowable Deflection

4.2 Tegangan Normal

Pada gambar 3.5 (a) merupakan distribusi dari tegangan normal hydraulic lifting machine setelah dilakukan simulasi dengan beban kerja maksimal $1000 \mathrm{~kg}$, dimana tegangan normal maksimumnya berada pada lubang baut yang ditunjukkan pada gambar 3.5 (b).

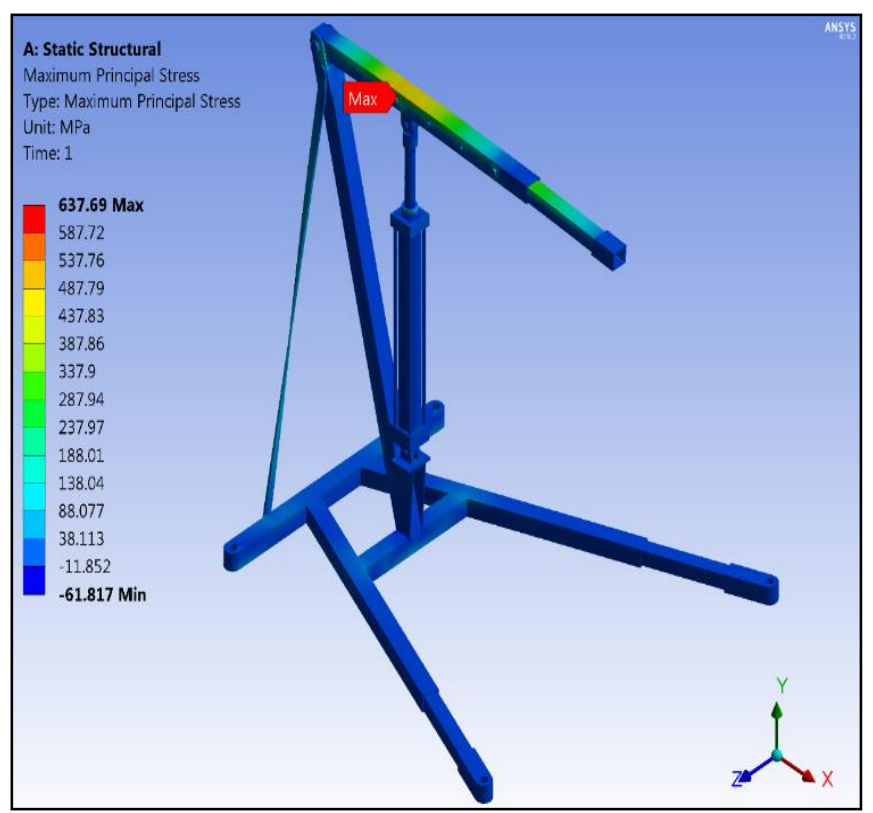




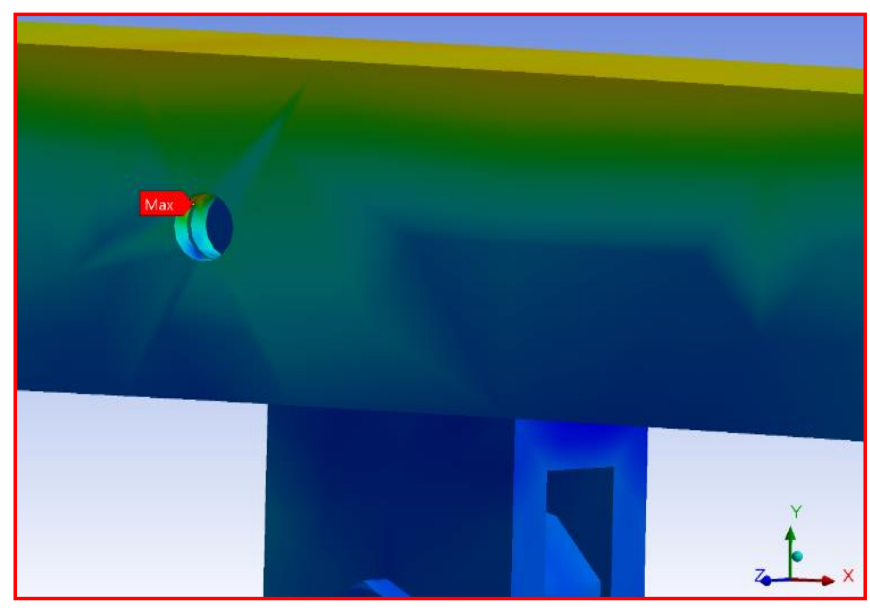

Gambar 3.5 (a) Distribusi Tegangan Normal Pada Hydraulic Lifting Machine Dengan Beban Kerja 1000 kg, (b) Pembesaran Pada Bagian Yang Mengalami Kosentrasi Tegangan

Data nilai tegangan normal yang timbul pada struktur hydraulic lifting machine dari kedua jenis analisis dengan konmasing-masing kondisi beban kerja ditunjukkan pada tabel 5 .

Tabel 5 Data Perbandingan Hasil Analisis Tegangan Normal

\begin{tabular}{cccc}
\hline \multicolumn{4}{c}{ Maksimal Tegangan Normal } \\
\hline $\begin{array}{c}\text { Load } \\
(\mathrm{kg})\end{array}$ & $\begin{array}{c}\text { Kalkulasi } \\
(\mathrm{MPa})\end{array}$ & $\begin{array}{c}\text { Simulasi } \\
(\mathrm{MPa})\end{array}$ & $\begin{array}{c}\text { Margin } \\
(\%)\end{array}$ \\
\hline 100 & 60,133 & 67,391 & 5,7 \\
250 & 150,331 & 162,44 & 3,9 \\
500 & 300,663 & 320,86 & 3,2 \\
750 & 450,994 & 479,27 & 3 \\
1000 & 601,326 & 637,69 & 2,9 \\
\hline
\end{tabular}

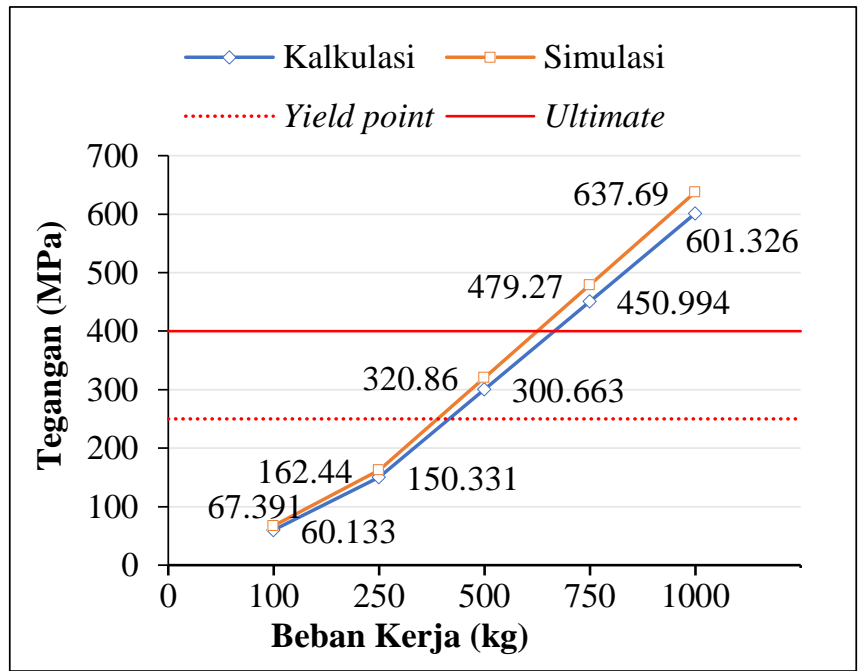

Gambar 3.6 Grafik Nilai Tegangan Normal Terhadap

Nilai Kekuatan Bahan Baja ASTM-A36

Berdasarkan pada Tabel 5 menunjukkan bahwa nilai tegangan normal yang timbul pada struktur hydraulic lifting machine dari kedua jenis analisis terdapat selisih hingga sebesar 5,7\%. yang dilukiskan kedalam grafik pada Gambar 3.6 dimana hasil simulasi tegangan normal yang timbul pada struktur hydraulic lifting machine yang mana pada beban kerja $500 \mathrm{~kg}$ nilai tegangan normal yang timbul telah melewati batas tegangan luluh bahan baja ASTM-A36 (250 $\mathrm{MPa}$ ) sehingga akan menyebabkan bertambahnya nilai regangan secara terus pada boom meskipun beban kerja tetap dan pada kondisi beban kerja $750 \mathrm{~kg}$ keatas nilai tegangan normal yang timbul telah melewati batas tegangan ultimate bahan baja ASTM-A36 (400 MPa) sehingga akan menyebabkan rangka boom patah atau putus.

\subsection{Tegangan Von Mises}

Hasil dari simulasi tegangan von Mises pada struktur hydraulic lifting machine diharapkan berada dibawah nilai tegangan ijin (allowable stress) berdasarkan AISC: Steel Spesification for Structural Steel Buildings, peraturan Allowable Stress Design (ASD) untuk dinyatakan aman nilai batas maksimal tegangan resultannya adalah :

$$
\begin{aligned}
\mathrm{R}_{\mathrm{a}} & \leq \frac{\mathrm{R}_{\mathrm{n}}}{\Omega} \\
& \leq \frac{250 \mathrm{MPa}}{1,67} \\
& \leq 149,7 \mathrm{MPa}
\end{aligned}
$$

Dimana:

$$
\begin{aligned}
& \mathrm{Ra}=\text { Batas tegangan ijin (allowable stress) } \\
& \mathrm{Rn}=\text { Kekuatan luluh material } \\
& \Omega=\text { Safety factor }
\end{aligned}
$$

Pada gambar 3.7 (a) merupakan distribusi dari tegangan von Mises yang timbul pada hydraulic lifting machine setelah dilakukan simulasi dengan beban kerja maksimal $1000 \mathrm{~kg}$, yang mana tegangan resultan maksimumnya berada pada lubang baut boom yang ditunjukkan pada gambar 3.7 (b).

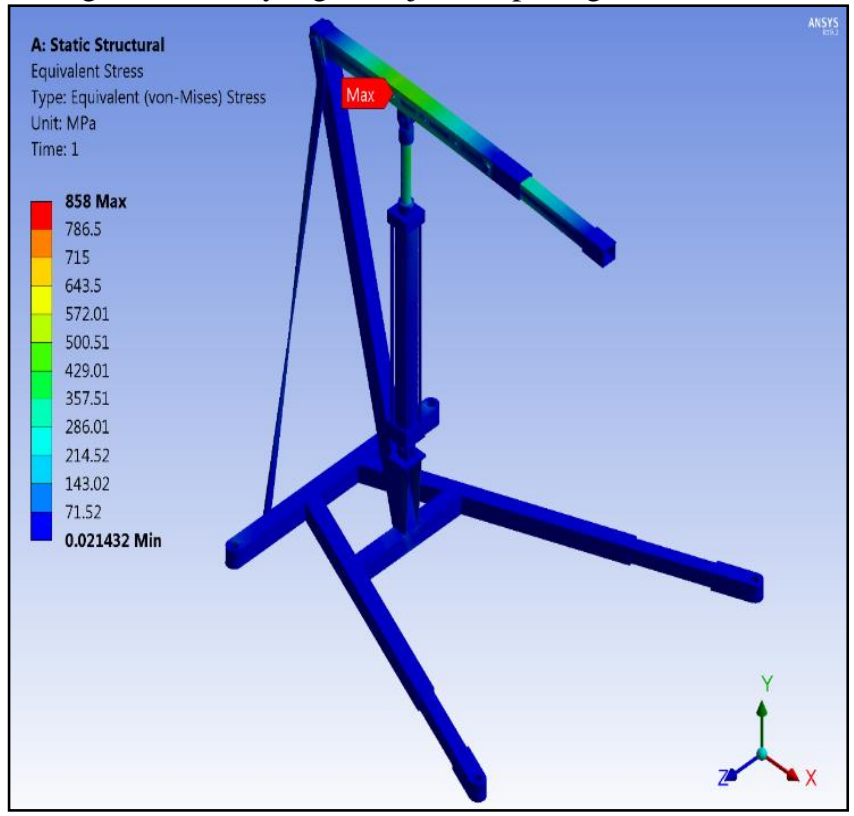




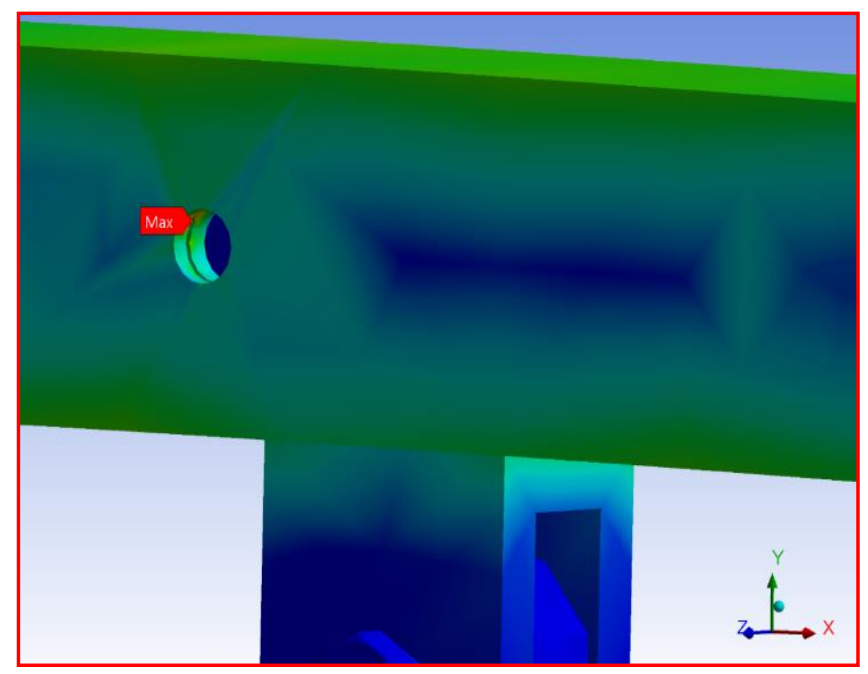

Gambar 3.7 (a) Distribusi Tegangan Von Mises Pada Hydraulic Lifting Machine Dengan Beban Kerja $1000 \mathrm{Kg}$, (b) Pembesaran Pada Bagian Yang Mengalami Kosentrasi Tegangan

Data hasil simulasi tegangan von Mises yang timbul pada struktur hydraulic lifting machine dengan masing-masing kondisi beban kerja ditunjukkan pada tabel 4.4.

Tabel 6 Data Hasil Simulasi Tegangan Von Mises

\begin{tabular}{ccc}
\hline \multicolumn{3}{c}{ Equivalent Stress $\left(\sigma_{\mathrm{e}}\right)$} \\
\hline $\begin{array}{c}\text { Load } \\
(\mathrm{kg})\end{array}$ & $\begin{array}{c}\text { Maximum }\left(\sigma_{\mathrm{e}}\right) \\
(\mathrm{MPa})\end{array}$ & $\begin{array}{c}\text { Allowable Stress }\left(\sigma_{\mathrm{e}}\right) \\
(\mathrm{MPa})\end{array}$ \\
\hline 100 & 90,616 & \\
250 & 218,51 & 149,7 \\
500 & 431,68 & \\
750 & 644,84 & \\
1000 & 858 & \\
\hline
\end{tabular}

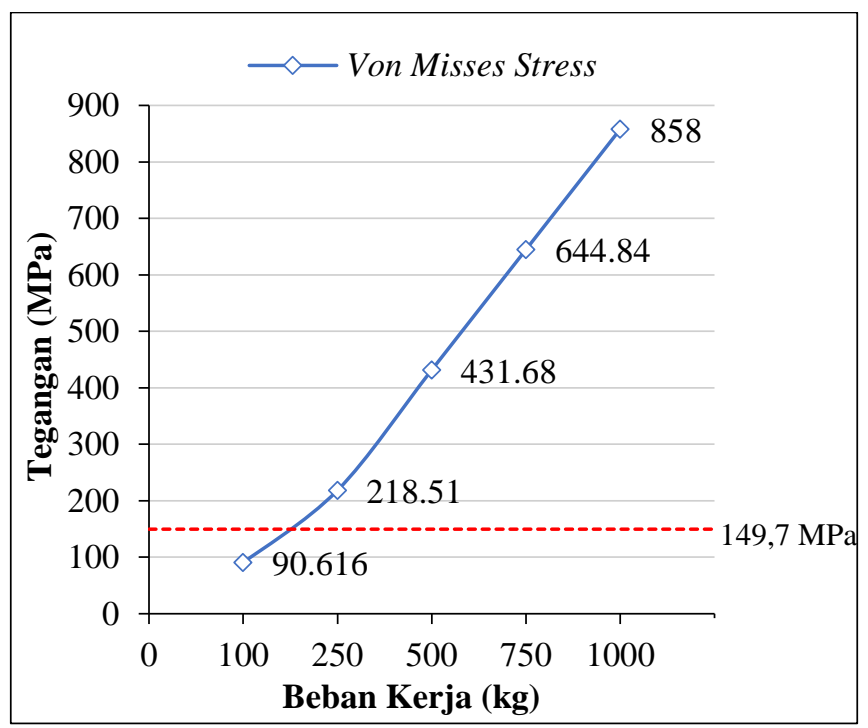

Gambar 3.8 Grafik Nilai Tegangan Von Mises Terhadap Nilai Batas Tegangan Ijin

Berdasarkan pada Gambar 3.8 menunjukkan bahwa nilai tegangan von Mises yang timbul pada struktur hydraulic lifting machine dari kelima jenis kondisi beban kerja nilai tegangan resultannya yang berada dibawah batas tegangan ijin adalah hanya pada beban kerja $100 \mathrm{~kg}$ sehingga dapat disimpulkan bahwa hydraulic lifting machine layak digunakan dengan kondisi beban kerja maksimal $100 \mathrm{~kg}$.

Angka safety factor pada struktur hydraulic lifting machine berdasarkan kekuatan dari nilai yield strength dan tegangan von Mises yang bekerja pada masing-masing Load Case yaitu:

1. Beban $100 \mathrm{~kg}$

$$
\mathrm{SF}=\frac{\text { Yield strength }}{\sigma \max }=\frac{250 \mathrm{MPa}}{98,474 \mathrm{MPa}}=2,5
$$

2. Beban $250 \mathrm{~kg}$

$$
\mathrm{SF}=\frac{\text { Yield strength }}{\sigma \max }=\frac{250 \mathrm{MPa}}{238,34 \mathrm{MPa}}=1,05
$$

3. Beban $500 \mathrm{~kg}$

$$
\mathrm{SF}=\frac{\text { Yield strength }}{\sigma \max }=\frac{250 \mathrm{MPa}}{470,89 \mathrm{MPa}}=0,53
$$

4. Beban $750 \mathrm{~kg}$

$$
\mathrm{SF}=\frac{\text { Yield strength }}{\sigma \max }=\frac{250 \mathrm{MPa}}{703,45 \mathrm{MPa}}=0,36
$$

5. Beban $1000 \mathrm{~kg}$

$$
\mathrm{SF}=\frac{\text { Yield strength }}{\sigma \max }=\frac{250 \mathrm{MPa}}{936 \mathrm{MPa}}=0,27
$$

\section{Kesimpulan}

Berdasarkan hasil dari analisis yang telah dilakukan baik simulasi maupun kalkulasi secara teori metode elemen hingga, Maka dapat ditarik beberapa kesimpulan, sebagai berikut:

1. Nilai tegangan resultan yang timbul pada struktur hydraulic lifting machine yang mana pada beban kerja lebih dari $100 \mathrm{~kg}$ nilai tegangan resultannya telah melebihi batas tegangan ijin yang telah ditentukan yakni sebesar 149,7 MPa. Sehingga hydraulic lifting machine layak digunakan dengan beban kerja maksimal $100 \mathrm{~kg}$ dengan angka safety factor sebesar 2,5 .

2. Nilai defleksi maksimum yang timbul pada boom hydraulic lifting machine dari kelima jenis beban kerja hanya pada beban kerja $100 \mathrm{~kg}$ yang berada dibawah batas defleksi ijin yang telah ditentukan yaitu sebesar $7,78 \mathrm{~mm}$. Sehingga hydraulic lifting machine aman digunakan dengan beban kerja maksimal sebesar 100 $\mathrm{kg}$.

\section{Daftar Pustaka}

Agustin, S. E., Sutantra, I. 2018. Analisis Struktur dan Redesign Tower Crane Potain MD 900. Jurnal Teknik. Vol. 7 (1): 231-236

American National Standard Institute. AISC: Specification for Structural Steel Buildings. 2005. Chicago: AISC Inc.

Cook, R. D., Malkus, D. S., Plesha, M. E., Witt, R. J.;2001; Concept and Applications of Finite Element Analysis; Edisi 4; University of Wisconcin; Madison.

Handoko, A. T., Adib, A. K., Basrini, Munir, Hadi, S., 2015. Rancang Bangun Hydraulic Lifting Machine Dengan 
Kapasitas Angkat Maksimal 1000kg. Proyek Akhir. Sekolah Tinggi Teknologi Ronggolawe. Cepu.

Kelana, D., Ariatedja, J. 2018. Analisa Dan Size Optimization Jib Boom Hydraulic Crane Dengan Metode Elemen Hingga. Jurnal Teknik. Vol. 7 (2): 306-311.

Logan, D.;2012; A First Course in the Finite Element Method; Edisi 3; Cengage Learning; Stamford.

Mohammad, A., Sugiyanto, 2009. Analisa Tegangan Dan Regangan Pada Struktur Container Crane Kapasitas 40 Ton Menggunakan Metode Elemen Hingga. Rotasi. (11); 1-4. Paggaru, I.; 2014; Metode Elemen Hingga : Teori Dan Konsep Dasar; Edisi 1; Yayasan Jhon Hi-Tech Idetama; Jakarta.

Zainuri, A. M.; 2010; Mesin Pemindah Bahan (Material

Handling Equipment); $\quad$ Edisi 2; Andi; Yogyakarta. 